\title{
EFEKTIVITAS PENEGAKAN HUKUM TERHADAP PRODUSEN MAKANAN DI INDONESIA
}

\author{
${ }^{1}$ Ruli Purnamasari, ${ }^{2}$ Solihan, ${ }^{3}$ Viyola Azzahra \\ ${ }^{123}$ Anggota Ikatan Dokter Indonesia (IDI) Cabang Kota Pekanbaru \\ Email: ${ }^{1}$ ruli_purnamasari@yahoo.com, ${ }^{2}$ solihanlihann@gmail.com, ${ }^{3}$ vylzzhr@yahoo.com
}

\section{Info Artikel:}

Diterima: 13 Agustus 2019 | Disetujui: 14 September 2019

| Dipublikasikan: 27 Desember 2019

\begin{abstract}
Abstrak
Efektivitas penegakan hukum terhadap produsen makanan berbahaya menuju Indonesia Sehat 2025 tersebut didasarkan apabila pelaku usaha memproduksi dan memperdagangkan produk makanan yang mengandung bahan kimia serta membahayakan kesehatan dan keselamatan konsumen, maka pelaku usaha/produsen melanggar Undang-Undang Nomor 36 Tahun 2009 tentang Kesehatan, Undang-Undang Nomor 18 Tahun 2012 tentang Pangan, Undang-Undang Nomor 8 Tahun 1999 tentang perlindungan Konsumen. Penelitian ini merupakan penelitian hukum normative yang bertujuan untuk mengetahui Faktor yang mempengaruhi terhadap efektivitas penegakan hukum terhadap produsen makanan berbahaya menuju Indonesia Sehat 2025. Faktor hukumnya, yaitu lemahnya sanksi terhadap pelanggarnya, proses penanganan masalah berbelit-belit, kurang profesionalnya para aparatur penegak hukum dan kurangnya koordinasi antar penegak hukum. Tanggung jawab pidana produsen terhadap kerugian yang diderita konsumen akibat makanan berbahaya yang diproduksi, dipasarkan, ditawarkan dan diperdagangkannya, secara yuridis, dalam konsepsi Undang-Undang Perlindungan Konsumen dan peraturan perundang-undangan terkait lainnya.
\end{abstract}

Kata Kunci: Efektivitas, Penegakan Hukum, Produsen Makanan

\section{THE EFFECTIVENESS OF LAW ENFORCEMENT ON FOOD MANUFACTURERS IN INDONESIA}

\begin{abstract}
The effectiveness of law enforcement against dangerous food producers towards Healthy Indonesia 2025 is based on if business actors produce and trade food products that contain chemicals and endanger the health and safety of consumers, then the business actor/producer violates Law Number 36 of 2009 concerning Health, Law No. Law Number 18 of 2012 concerning Food, Law Number 8 of 1999 concerning Consumer Protection. This research is a normative legal research that aims to determine the factors that influence the effectiveness of law enforcement against producers of dangerous food towards Healthy Indonesia 2025. The legal factors are the weakness of sanctions against violators, the process of handling problems is complicated, the lack of professionalism of law enforcement officials and the lack of coordination between law enforcement. The producer's criminal responsibility for the loss suffered by the consumer due to the dangerous food produced, marketed, offered and traded, legally, in the conception of the Consumer Protection Act and other relevant laws and regulations.
\end{abstract}

Keywords: Effectiveness, Law Enforcement, Food Producers 


\section{A. PENDAHULUAN}

Tercapainya hak hidup sehat bagi seluruh lapisan masyarakat melalui sistem kesehatan yang dapat menjamin hidup dalam lingkungan yang sehat, perilaku masyarakat proaktif memelihara kesehatannya serta mampu melakukan akses dalam pelayanan kesehatan yang bermutu sesuai yang tertera dalam kebijakan pembangunan jangka panjang bidang kesehatan Menuju Indonesia Sehat 2025. Pada prinsipnya pembangunan kesehatan adalah upaya yang dilaksanakan oleh semua komponen bangsa Indonesia yang bertujuan untuk meningkatkan kesadaran, kemauan, dan kemampuan hidup sehat bagi setiap orang agar terwujud derajat kesehatan masyarakat yang setinggitingginya, sebagai investasi bagi pembangunan sumber daya manusia yang produktif secara sosial dan ekonomis. ${ }^{1}$

Kesehatan merupakan salah satu unsur kebutuhan dasar manusia yang harus terpenuhi. Salah satu penunjang kesehatan adalah dengan makanan. Makanan merupakan salah satu kebutuhan pokok yang sangat diperlukan oleh manusia. Manusia tidak bisa dipisahkan dengan makanan, karena makanan menjadi penopang energi untuk melakukan kegiatan sehari-hari. $^{2}$

Didalam Pasal 1 Undang-Undang No. 18 tahun 2012 tentang Pangan dijelaskan bahwa pangan adalah segala sesuatu yang berasal dari sumber hayati produk pertanian, perkebunan, kehutanan, perikanan, peternakan, perairan dan air, baik yang diolah maupun yang tidak diolah yang dipruntukan sebagai makanan atau minuman bagi konsumsi manusia, termasuk bahan tambahan pangan, bahan baku pangan, dan bahan lainnya yang digunakan dalam proses penyiapan, pengolahan dan/atau pembuatan makanan dan minuman. $^{3}$

Banyak produsen berlomba-lomba untuk membuat atau memproduksi makanan dengan modal yang sedikit dan mendapat keuntungan yang banyak. Pemikiran menggunakan modal sedikit dan mendapatkan untung yang banyak membuat produsen tidak mematuhi keamanan, kemurnian dan higienis nya makanan. Produsen dalam memproduksi makanan harus selalu mematuhi peraturan perundang- undangan. Tidak hanya peraturan perundang-undangan akan tetapi Indonesis, Rencana Pembangunan Jangka Panjang Bidang Kesehatan, Jakarta, 2009.

\footnotetext{
${ }^{2}$ Ditjen PPM \& PL., Prinsip Hygiene dan Sanitasi Makanan, Jakarta, 2001.

${ }^{3}$ Pasal 1 Undang-Undang Nomor 18 Tahun 2012 tentang Pangan.
} 
juga menerapkan sistem manajemen pangan yang komprehensif didalam industri. ${ }^{4}$

Penegakan hukum terhadap pelaku kejahatan, seperti kejahatan pencurian, pembunuhan, termasuk kejahatan yang dilakukan produsen makanan yang mengandung zat berbahaya. Zat berbahaya dimaksud seperti, Rhodamin B, Boraks, dan Formalin yang sengaja dimasukan pada makanan sehingga sangat membahayakan kesehatan bahkan mengancam nyawa. Dalam melakukan penegakan hukum pada bidang obat dan makanan, Badan Pengawas Obat dan Makanan Republik Indonesia menjadi institusi utama dalam mengembannya. Hal ini tertuang dalam Pasal 67 Keputusan Presiden Nomor 103 Tahun 2001 bahwa Badan Pengawas Obat dan Makanan Republik Indonesia melaksanakan tugas pemerintahan di Bidang Pengawasan Obat dan Makanan sesuai dengan ketentuan peraturan perundang-undangan yang berlaku. ${ }^{5}$

Penegakan hukum dalam bidang obat dan makanan yang dilakukan oleh Badan Pengawas Obat dan Makanan Republik Indonesia terkait dengan pengawasan, pemeriksan dan penyidikan telah dilakukan secara rutin sebagai tanggung jawab pemerintah sebagaimana

4 Yusuf Shofie, Kapita Selekta Hukum Perlindungan Konsumen Di Indonesia, (Bandung: Citra Aditya Bakti, 2008), hlm. 3-4.

${ }^{5}$ Hasil Kajian BPKN Di Bidang Pangan Terkait Perlindungan Konsumen, melalui http://www.indonesia.go.id/id/index.php. yang diamanatkan oleh presiden dalam keputusan seperti yang disebutkan diatas. Dalam rangka memberantas dan menertibkan peredaran produk obat dan makanan ilegal termasuk palsu serta obat keras disarana yang tidak berhak, Badan Pengawas Obat dan Makanan Republik Indonesia telah melakukan investigasi awal dan penyidikan kasus tindak pidana di bidang obat dan makanan. Upaya ini dilakukan secara mandiri maupun bersinergi dengan instansi penegak hukum lainnya (dalam kerangka Operasi Gabungan Daerah, Operasi Gabungan Nasional dan Operasi Satgas Pemberantasan Obat dan Makanan Ilegal). ${ }^{6}$

Selama tahun 2014 ditemukan 583 kasus pelanggaran di bidang obat dan makanan. Dari total kasus tersebut, 202 kasus ditindaklanjuti dengan pro justitia dan 381 kasus ditindaklanjuti dengan sanksi administratif. ${ }^{7}$ Tidak kurang dari 200 kasus tindak pidana dalam bidang obat dan makanan yang dilakukan penyidikannya setiap tahun. Artinya dalam lima tahun terakhir tidak kurang dari 1000 kasus obat dan makanan di seluruh Indonesia yang telah disidangkan dan telah diputuskan oleh

${ }^{6}$ Liss Dyah Dewi Arini, Faktor-Faktor Penyebab Dan Karakteristik Makanan Kadaluarsa Yang Berdampak Buruk Pada Kesehatan Masyarakat, Jurnal APIKES, Surakarta, Citra Medik, 2017.

7 Roy A Sparringa, Laporan Tahunan Badan Pengawas Obat dan Makanan Republik Indonesia tahun 2014, Badan POM RI, Februari 2015, hlm.33 
pengadilan yang berkekuatan hukum tetap. ${ }^{8}$ Sehingga menjadi sebuah pertanyaan mendasar yang hingga kini belum terjawab apakah penegakan hukum kesehatan dalam bidang obat dan makanan di Indonesia sudah berjalan sebagaimana yang diharapkan ataukah belum berjalan sebagaimana mestinya. Oleh karena itu perlu dilakukan sebuah studi dan kajian mendalam untuk melihat dan menilai efektivitas penegakan hukum terhadap produsen makanan berbahaya menuju Indonesia Sehat 2025.

Berdasarkan deskripsi latar belakang masalah dapat dirumuskan permasalahan pokok penelitian ini, yaitu: Bagaimanakah pertanggungjawaban hukum pidana terhadap produsen makanan berbahaya, bagaimanakah efektivitas penegakan hukum pidana terhadap produsen makanan berbahaya menuju Indonesia Sehat 2025? Apakah kendala terhadap efektivitas penegakan hukum terhadap produsen makanan berbahaya menuju Indonesia Sehat 2025? Tulisan ini akan menjawab beberapa pertanyaaan tersebut.

\section{B. METODE PENELITIAN}

Penelitian hukum adalah suatu kegiatan ilmiah yang didasarkan pada

8 Muhammad Rusydi Ridha, Efektivitas Penegakan Hukum Pidana Kesehatan Dalam Bidang Obat Dan Makanan Di Indonesia, Tesis, Program Masgister IImu Hukum Program Pascasarjana Fakultas Hukum Universitas Islam Indonesia, 2017, hlm. 6. metode, sistematika, dan pemikiran tertentu yang bertujuan untuk mempelajari satu atau beberapa gejala hukum tertentu dengan jalan menganalisanya. ${ }^{9}$ Metode yang digunakan dalam penelitian ini adalah penelitian yuridis normatif, sedangkan desain penelitian yang digunakan adalah penelitian deskriptif, termasuk studi formulatif dan eksploratif yang hendak mengenal untuk keperluan studi selanjutnya. ${ }^{10}$ Penelitian ini bertujuan untuk menyelidiki hal-hal yang berkaitan dengan hukum, baik hukum formal maupun non formal melalui studi kepustakaan yang digunakan untuk membantu melengkapi artikel ini dengan berbagai sumber bacaan, seperti buku teks, jurnal, dan lain sebagainya yang terkait dengan permasalahan yang sedang diteliti.

\section{HASIL DAN PEMBAHASAN}

\section{Pertanggungjawaban Hukum Pidana Terhadap Produsen Makanan Berbahaya}

Istilah Product Liability baru dikenal sekitar 60 tahun yang lalu, yaitu dalam dunia perasuransian di Amerika Serikat sehubungan dengan dimulainya produksi bahan makanan secara besar-besaran baik kalangan produsen maupun penjual mengasuransikan barang-barangnya

\footnotetext{
${ }^{9}$ Soerjono Seokanto, Pengantar Penelitian Hukum, (Jakarta: UI Press, 2007), hlm. 43.

${ }^{10}$ Moh. Nazir, Metode Penelitian, (Bogor: Ghalia Indonesia, 2014), hlm. 75.
} 
terhadap kemungkinan adanya kerugian terhadap para konsumen. Produk adalah barang atau jasa yang dibuat atau ditambah gunanya atau nilainya dalam proses produksi dan menjadi hasil akhir dari proses produksi itu, atau benda atau yang bersifat kebendaan seperti barang, bahan, atau bangunan yang merupakan hasil konstruksi. ${ }^{11}$

Berkaitan dengan pengertian istilah produk cacat/rusak (defective product), yang menyebabkan produsen harus bertanggungjawab, dikenal juga tiga macam defect, yaitu: Production/Manufacturing Defect, Design Defect, Dan Warning Or Instruction Defect. Pertama, Production/Manufacturing Defects, yaitu: jika suatu produk dibuat tidak sesuai dengan persyaratan sehingga akibatnya produk tersebut tidak aman bagi konsumen. Kedua, Design Defect, yaitu: jika bahaya dari produk tersebut lebih besar daripada manfaat yang diharapkan oleh konsumen biasa atau bila keuntungan dari desain produk tersebut lebih kecil dari resikonya. Ketiag, Warning/Instruction Defects, yaitu: jika buku pedoman, buku panduan, pengemasan, etiket tidak cukup memberikan peringatan tentang bahaya yang mungkin timbul dari produk tersebut atau petunjuk penggunaannya yang aman. ${ }^{12}$

Dalam memasuki era industrialisasi berbagai hal yang perlu mendapat perhatian sungguh-sungguh, mulai dari penyediaan sumber daya manusia yang berkualitas, penguasaan ilmu dan tekhnologi, mengantisipasi tuntutan akan barang dan jasa yang lebih berkualitas. hal lain yang perlu mendapat perhatian serius dalam era industrialisasi adalah bidang hukum. Khususnya tentang tanggungjawab produk (product liability) atau tanggungjawab produsen. Indonesia sampai saat ini belum memiliki peraturan perundang-undangan yang khusus mengatur tentang tanggungjawab produsen. Oleh karena itu bila seorang konsumen menderita kerugian akibat produk yang cacat dan ingin menuntut pihak produsen, maka upaya hukum yang dapat ditempuh hanyalah berdasarkan perbuatan melawan hukum. Dalam memberlakukan prinsip tanggung jawab mutlak (strict liability) dalam hukum tentang product liability tidak berarti produsen tidak mendapatkan perlindungan. Pihak produsen masih diberi kesempatan untuk membebaskan diri dari tanggungjawabnya dalam hal-hal tertentu yang dinyatakan dalam undang-undang. Disamping itu pihak produsen juga dapat

12 H.E Saefullah. Hukum Perlindungan Konsumen Di Indonesia. Citra Aditya Bakti, Bandung 1991, Hlm. 4-5. 
mengasuransikan tanggung jawabnya sehingga secara ekonomis produsen tidak mengalami kerugian yang berarti. ${ }^{13}$

Apabila ingin mengetahui ruang lingkup dari product liability tersebut bisa dilihat prakteknya pada negara lain. Dengan melihat pengalaman praktek dari masyarakat Eropa, terutama Belanda, menurut Yusuf Shofie dapat dikemukakan ciri-ciri atau ruang lingkup product liability sebagai berikut: a. yang dapat dikualifikasikan sebagai produsen adalah : 1. Pembuat produk jadi (finished product); 2. Penghasil bahan baku; 3. Pembuat suku cadang; 4. Setiap orang yang menampakan dirinya sebagai produsen, dengan jalan menantumkan namanya, tanda pengenal tertentu, atau tanda lain yang membedakan dengan produk asli pada produk tertentu; 5 . Importir suatu produk dengan maksud untuk dijualbelikan, disewakan, disewagunakan (leasing) atau bentuk distribusi lain dalam transaksi perdagangan; 6. Pemasok (supplier), dalam hal identitas dari produsen atau importir tidak dapat ditentukan. b. Yang dapat dikualifikasikan sebagai konsumen adalah konsumen akhir. c. Yang dapat dikualifikasikan sebagai produk adalah benda bergerak maupun tidak bergerak. d. Yang dapat

13 Nur Rachmat, Penyidikan Dan Pertanggungjawaban Pidana Produsen Terhadap Produk Makanan Mengandung Kimia Berbahaya, Jurnal Ilmu Hukum Legal Opinion, Edisi 4, Volume 2, Tahun 2014, hlm. 40. dikualifikasikan sebagai kerugian adalah kerugian pada manusia (death atau personal injury) dan kerugian pada harta benda, selain dari produk yang bersangkutan. e. Produk dikualifikasikan sebagai mengandung kerusakan apabila produk tersebut tidak memenuhi keamanan (safety) yang dapat diharapkan oleh seorang dengan mempertimbangkan semua aspek, antara lain : 1. Penampilan produk (the presentation of the product). 2. Maksud penggunaan produk (intended use the product). 3. Saat ketika produk ditempatkan di pasaran (the time when the product was put into circulation). ${ }^{14}$

Berkenaan hal tersebut, cakupan product liabilty menunjukan luasnya kepentingan konsumen. Dari pengertian produk dan produsen yang begitu luas dapat diasumsikan baha melalui product liabilty, secara formal kepentingan konsumen dapat terlindungi, karena dapat diketahui apa yang dapat dituntut dan kepada siapa tuntutan ituharus diajukan. Berkaitan dengan sistem tanggung jawab produk (product liabilty), menurut Hartarto Winoto ada baiknya dikemukakan tentang adanya beberapa teori yang dapat dikemukakan kaitannya dengan tanggung jawab, yaitu : a. Prinsip tanggung jawab berdasarkan atas adanya unsur kesalahan (fault liability), liability based on fault principle). b. Prinsip

14 Yusuf Shofie, Kapita Selekta Hukum Perlindungan ..... Loc. Cit. 
tanggung jawab berdasarkan atas praduga (refutable presumption of liability principle). c. Prinsip tanggung jawwab mutlak (non faulth liability, absolute atau strict liability principle). ${ }^{15}$

Lebih lanjut menurut Hartarto Winoto bahwa prinsip atau teori tentang tanggung jawab sebagaimana di kemukakan di atas satu sama lain menunjukan adanya perbedaan dilihat dari segi pembuktian. Pada prinsipnya tanggung jawab liability based on fault, seorang tergugat harus membayar ganti rugi atas kerugian yang diderita penggugat, apabila penggugat mampu membuktikan adanya kesalahan pada pihak tergugat. unsur kesalahan merupakan unsur mutlak, sehingga dapat dirumuskan tiada tanggung jawab tanpa kesalahan (no liability without fault). ${ }^{16}$

Dengan lembaga product liability, konsumen sebagai korban atas produk cacat atau rusak akan terlindungi. Hal ini paling tidak tampak dari segi tanggung jawab mutlak (strict liability) yang dianut dan segi beban pembuktian yang menjadi beban produsen. Di samping itu, konsumen yang dirugikan dapat menuntut ganti rugi Kepada produsen meskipun tidak terdapat hubungan kontraktual (privity of contract).

Larangan Menambahkan bahanbahan berbahaya atau bahan kimia ke

\footnotetext{
${ }^{15}$ Hartarto Winoto, Perlindungan Hukum Konsumen., (Jakarta: Salemba Empat, 2000), hlm. 36.

$$
{ }^{16} \text { Ibid, hlm. } 37 .
$$
}

dalam produk makanan, sebenarnya sudah sangat jelas diatur dalam Undang-Undang Kesehatan, Undang-Undang Pangan dan Undang-Undang Perlindungan Konsumen. Artinya Polisi, Pengawasan Obat dan Makanan tidak akan kekurangan aturan hukum untuk menjerat para penjual bahan kimia yang disalahgunakan untuk bahan tambahan makanan. Dengan adanya seperangkat produk hukum yang mengatur larangan bahan-bahan berbahaya masuk ke dalam makanan, tanpa harus ada laporan dari masyarakat, aparat baik Polisi, Kementerian Kesehatan maupun Balai Pengawasan Obat dan Makanan harus proaktif mengambil tindakan. ${ }^{17}$

\section{Efektivitas Penegakan Hukum} Pidana Terhadap Produsen Makanan Berbahaya Di Indonesia

Penegakan hukum pidana adalah upaya untuk mewujudkan keinginan hukum pidana menjadi kenyataan, menurut Van Hammel hukum pidana merupakan keseluruhan dasar dan aturan yang dianut oleh suatu negara dalam kewajibannya untuk menegakkan hukum, yaitu dengan melarang apa yang bertentangan dengan hukum dan menegakan hukuman kepada yang melanggar larangan tersebut. ${ }^{18}$

\footnotetext{
17 Nur Rachmat, Penyidikan Dan Pertanggungjawaban Pidana Produsen Terhadap Produk Makanan Mengandung Kimia Berbahaya, ..... Op. Cit., hlm. 10.

18 Satjipto Rahardjo, Ilmu Hukum. (Bandung: Citra Aditya Bakti, 2012), hlm. 120.
} 
Penegakan hukum pidana bersifat formal, prosedurnya harus dilaksanakan oleh empat komponen yang saling berkaitan satu sama lain yaitu penyidikan oleh polisi, penuntutan oleh jaksa, pemeriksaan di sidang pengadilan oleh hakim, dan pembinaan cara pidana oleh lembaga pemasyarakatan. ${ }^{19}$

Sehubungan dengan persoalan efektivitas hukum, pengidentikkan hukum tidak hanya dengan unsur paksaan eksternal, namun juga dengan proses pengadilan. Ancaman paksaan pun merupakan unsur yang mutlak ada agar suatu kaidah dapat dikategorikan sebagai hukum, maka tentu saja unsur paksaan inipun berkaitan erat dengan efektif atau tidaknya suatu ketentuan atau aturan hukum. Jika suatu aturan hukum tidak efektif, salah satu pertanyaan yang dapat muncul ialah, apa yang terjadi dengan ancaman paksaannya? Mungkin tidak efektifnya hukum disebabkan ancaman paksaannya kurang berat; mungkin juga disebabkan ancaman paksaan itu tidak terkomunikasi secara memadai pada warga masyarakat. $^{20}$

\section{Efektivitas hukum berarti} membahas daya kerja hukum itu dalam mengatur dan atau mengajak masyarakat untuk taat terhadap hukum. Hukum dapat

19 Nita Dkk, Penegakan Hukum Pidana Terhadap Produsen Pangan Yang Mengandung Zat Berbahaya, Journal Fakultas Hukum, 2017, hIm. 3.

${ }^{20}$ Achmad Ali, Menjelajahi Kajian Empiris Terhadap Hukum, (Jakarta: Yarsif Watampone, 1998), hlm.186. efektif bila faktor-faktor yang mempengaruhi hukum tersebut dapat berfungsi dengan sebaik-baiknya. Penilaian aefektif atau tidaknya suatu peraturan perundang-undangan yang berlaku dapat dilihat dari perilaku masyarakat. Suatu hukum atau peraturan perundang-undangan akan efektif apabila warga masyarakat berperilaku sesuai dengan yang diharapkan atau dikehendaki oleh atau peraturan perundang-undangan tersebut mencapai tujuan yang dikehendaki, maka efektivitas hukum atau peraturan perundang-undangan tersebut telah dicapai. ${ }^{21}$

Dalam melakukan penegakan hukum bidang makanan dan obat, Badan Pengawas Obat dan Makanan Republik Indonesia menjadi institusi utama dalam mengembannya. Hal ini terdapat dalam Pasal 67 Keputusan Presiden Nomor. 103 Tahun 2001 bahwa Badan Pengawas Obat dan Makanan Republik Indonesia melaksanakan tugas pemerintahan di bidang pengawasan Obat dan Makanan sesuai dengan ketentuan peraturan perundang-undangan yang berlaku. Sebagai institusi yang mempunyai tugas pokok melakukan pengawasan terhadap obat dan makanan, Badan Pengawas Obat dan Makanan Republik Indonesia akan menindaklanjuti setiap pelanggaran di

21 Soerjono Soekanto, Efektivitas Hukum dan Penerapan Sanksi, (Bandung: Ramadja Karya, 1988), hlm. 80. 
bidang obat dan makanan dengan pemberian sanksi administratif dan sanksi pro-justitia/penyidikan. Apabila dalam pelanggaran tersebut terdapat dugaan tindak pidana, maka akan dikenakan sanksi projustitia. Sebagai dasar hukum dalam pelaksanaan di bidang penyidikan oleh Badan Pengawas Obat dan Makanan Republik Indonesia, yaitu: Undang-Undang Nomor 8 Tahun 1981 tentang Hukum Acara Pidana, Undang-Undang Nomor 36 Tahun 2009 tentang Kesehatan, UndangUndang Nomor 18 Tahun 2012 Tentang Pangan, Undang-Undang Nomor 5 Tahun 1997 tentang Psikotropika, Undang-Undang Nomor 35 Tahun 2009 tentang Narkotika, Peraturan Pemerintah Nomor 72 Tahun 1998 tentang Pengamanan Sediaan Farmasi dan Alat Kesehatan, Peraturan Pemerintah Nomor 69 Tahun 1999 tentang Label dan Iklan Pangan, Peraturan Pemerintah Nomor 28 Tahun 2004 Tentang Keamanan, Mutu dan Gizi Pangan, Peraturan Pemerintah No. 51 Tahun 2009 tentang Pekerjaan Kefarmasian, dan Peraturan

PemerintahNomor 44 Tahun 2010 tentang Prekursor. $^{22}$

Khusus untuk tindak pidana dalam bidang obat dan makanan, terdapat tiga pasal yang mengaturnya. Peretama, Tanggung Jawab Pidana Produk

22 Hasil Kajian BPKN Di Bidang Pangan Terkait Perlindungan Konsumen, Loc. Cit.
Berdasarkan UU No. 36 Tahun 2009 tentang Kesehatan. Berdasarkan sistem hukum yang ada kedudukan konsumen sangat lemah dibanding produsen. Salah satu usaha untuk melindungi dan meningkatkan kedudukan konsumen adalah dengan menerapkan prinsip tanggung jawab (strict liability) dalam hukum tentang tanggung jawab produsen. Barang siapa dengan sengaja: a. Mengedarkan makanan dan atau minuman yang tidak memenuhi standar dan atau persyaratan dan atau membahayakan kesehatan sebagaimana dimaksud dalam Pasal 196 ayat (2) dan ayat (3) dipidana dengan pidana penjara paling lama 10 (sepuluh) tahun dan denda paling banyak Rp 1.000.000.000,00 (satu miliar rupiah). b. Setiap orang yang dengan sengaja memproduksi atau mengedarkan sediaan farmasi dan/atau alat kesehatan yang tidak memiliki izin edar sebagaimana dimaksud dalam Pasal 106 ayat (1) dipidana dengan pidana penjara paling lama 15 (lima belas) tahun dan denda paling banyak Rp1.500.000.000,00 (satu miliar lima ratus juta rupiah) Pasal 197.

Kedua, Tanggung Jawab Pidana

Produk Berdasarkan Undang-Undang Nomor 18 Tahun 2012 tentang Pangan. Ketentuan Pidana dalam Undang-Undang Nomor 18 Tahun 2012 tentang Pangan yaitu: Pasal 55 Barangsiapa dengan sengaja: a. Menyelenggarakan kegiatan atau proses produksi, penyimpanan, 
pengangkutan, dan atau peredaran pangan dalam keadaan yang tidak memenuhi sanitasi sebagaimana termaksud dalam Pasal 8; b. Menggunakan barang yang dilarang digunakan sebagai bahan tambahan pangan atau menggunakan bahan tambahan pangan secara melampaui ambang batas maksimal yang ditetapkan, sebagaimana yang dimaksud dalam Pasal 10 ayat (1); c. Menggunakan barang yang dilarang digunakan sebagai kemasan pangan dan atau bahan apapun yang dapat melepaskan cemaran yang merugikan atau membahayakan kesehatan manusia, sebagaimana dimaksud dalam Pasal 16 ayat (1); d. Pasal 21 mengedarkan pangan yang dilarang untuk diedarkan, sebagaimana dimaksud dalam huruf a, huruf $b$, huruf $d$ atau e; e. Memperdagangkan pangan yang tidak memenuhi standar mutu yang dimaksudkan, sebagaimana dimaksud dalam pasal 26 huruf a; $f$. Memperdagangkan pangan yang mutunya berbeda atau tidak sama dengan mutu pangan yang dijanjikan, sebagaimana dimaksud dalam pasal 26 huruf b; g. Memperdagangkan pangan yang tidak memenuhi persyaratan sertifikasi mutu pangan, sebagaimana dimaksud dalam Pasal 26 huruf c; h. Mengganti, melabel kembali, atau menukar tanggal, bulan dan tahun kadaluarsa, pangan yang diedarkan, sebagaimana yang dimaksud dalam pasal 32; dipidana dengan pidana penjara paling lama 5 tahun dan atau denda paling banyak Rp. 600.000.000,- (Enam ratus juta rupiah).

\section{Pasal 56 Barangsiapa karena} kelalaiannya: a. Menyelenggarakan kegiatan atau proses produksi, penyimpanan, pengangkutan, dan atau peredaran pangan dalam keadaan yang tidak memenuhi sanitasi sebagaimana termaksud dalam pasal 8; b. Menggunakan barang yang dilarang digunakan sebagai bahan tambahan pangan atau menggunakan bahan tambahan pangan secara melampaui ambang batas maksimal yang ditetapkan, sebagaimana yang dimaksud dalalm Pasal 10 ayat (1); c. Menggunakan barang yang dilarang digunakan sebagai kemasan pangan dan atau bahan apapun yang dapat melepaskan cemaran yang merugikan atau membahayakan kesehatan manusia, sebagaimana dimaksud dalam Pasal 16 ayat (1); d.Pasal 21 mengedarkan pangan yang dilarang untuk diedarkan, sebagaimana dimaksud dalam huruf $a$, huruf $b$, huruf $d$ dan huruf e; dipidana dengan pidana penjara paling lama 1 tahun dan atau denda paling banyak Rp. 120.000.000,- (seratus dua puluh juta rupiah). Sementara Pasal 57 Ancaman pidana atas pelanggaran, sebagaimana dimaksud dalam pasal 55 huruf $a$, huruf $b$, huruf $c$, dan huruf $d$, serta pasal 56, ditambah seperempat apabila menimbulkan kerugian terhadap manusia atau ditambah sepertiga apabila menimbulkan kematian. 
Ketiga, Tanggung Jawab Pidana Produk Berdasarkan Undang-Undang Nomor 8 Tahun 1999 Tentang perlindungan Konsumen. Pada tanggal 20 April 1999, Pemerintah Republik Indonesia telah mengeluarkan dan mengundangkan Undang-Undang Nomor 8 Tahun 1999 tentang Perlindungan Konsumen. Undangundang ini dapat memberi jaminan kepastian hukum serta dapat memberi jaminan kepastian hukum serta dapat memberi landasan hukum yang lebih kuat dalam rangka meminta pertanggungjawaban produsen atas produk yang dihasilkannya yang telah menimbulkan kerugian terhadap konsumen. Undang-Undang Perlindungan Konsumen terdiri atas 15 bab dengan 65 Pasal pada pokoknya memuat tentang: Ketentuan Umum, Asas dan Tujuan, Hak dan Kewajiban (Konsumen atau Pelaku Usaha), perbuatan yang dilarang bagi pelaku usaha, ketentuan pencantuman tentang klausula baku, tanggung jawab pelaku usaha, pembinaan dan pengawasan. Perlindungan konsumen nasional, lembaga perlindungan konsumen swadaya masyarakat, penyelesaian sengketa, badan menyelesaian sengketa konsumen, penyidikan, sanksi, ketentuan peralihan, dan ketentuan penutup.

Keadaan masyarakat Indonesia pada masa depan atau visi yang ingin dicapai melalui pembangunan kesehatan dirumuskan sebagai: "Indonesia Sehat
2025". Dalam Indonesia Sehat 2025, lingkungan strategis pembangunan kesehatan yang diharapkan ialah lingkungan yang kondusif bagi terwujudnya keadaan sehat jasmani, rohani maupun sosial, yaitu lingkungan yang bebas dari kerawanan sosial budaya dan polusi, tersedianya air minum dan sarana sanitasi lingkungan yang memadai, perumahan dan pemukiman yang sehat, perencanaan kawasan yang berwawasan kesehatan, serta terwujudnya kehidupan masyarakat yang memiliki solidaritas sosial dengan memelihara nilai-nilai budaya bangsa. Perilaku masyarakat yang diharapkan dalam Indonesia Sehat 2025 adalah perilaku yang bersifat proaktif untuk memelihara dan meningkatkan kesehatan; mencegah risiko terjadinya penyakit; melindungi diri dari ancaman penyakit dan masalah kesehatan lainnya; sadar hukum; serta berpartisipasi aktif dalam gerakan kesehatan masyarakat, termasuk menyelenggarakan masyarakat sehat dan aman (safe community). ${ }^{23}$

Dalam rangka menuju Indonesia Sehat 2025 diharapkan masyarakat memiliki kemampuan menjangkau pelayanan kesehatan yang bermutu dan juga memperoleh jaminan kesehatan, yaitu masyarakat mendapatkan perlindungan

23 Departemen Kesehatan Republik Indonesia Jakarta, Rencana Pembangunan Jangka Panjang Bidang Kesehatan, 2009, Loc. Cit. 
dalam memenuhi kebutuhan dasar kesehatannya. Pelayanan kesehatan bermutu yang dimaksud adalah pelayanan kesehatan termasuk pelayanan kesehatan dalam keadaan darurat dan bencana, pelayanan kesehatan yang memenuhi kebutuhan masyarakat serta diselenggarakan sesuai dengan standar dan etika profesi. $^{24}$

\section{Faktor-faktor yang berpengaruh terhadap efektivitas penegakan hukum Terhadap Produsen} Makanan Berbahaya Di Indonesia

Setiap proses penegakan hukum terhadap sesuatu tindak pidana tentu tidak terlepas dari segala sesuatu yang bersifat menghambat dalam pelaksanaannya. Soerjono Soekanto mengemukakan beberapa faktor penghambat yang mempengaruhi penegakan hukum. Pertama, Faktor hukumnya sendiri. Dalam hal peraturan perundang-undangan yang mengatur mengenai hal tersebut, sebenarnya peraturan perundang-undangan yang ada sudah memadai, akan tetapi dengan maraknya berbagai kasus mengenai makanan dan minuman yang membahayakan kesehatan konsumen, bisa diketahui ada kelemahan yang mendasar, yaitu: a. Penegakan sanksi terhadap para pelanggarnya, b. Prosedur penanganan masalah masih mudah dimanfaatkan konsumen, c. Hukum acara yang berlaku pun tidak mudah dimanfaatkan konsumen,

\footnotetext{
${ }^{24}$ Ibid., hlm. 24.
}

dan d. Pengawasan peredaran bahan kimia belum maksimal. ${ }^{25}$

Kedua, Faktor Penegak Hukum. Dalam masalah ini masih kurangnya profesionalisme kerja para aparatur penegak hukum tersebut dalam menyelesaikan masalah berkenaan dengan penegakan hukum yang terjadi di masyarakat. Kurangnya koordinasi Balai Pengawasan Obat dan Makanan dengan Instansi terkait, seperti Kepolisian, Departemen Perdagangan. Balai Pengawasan Obat dan Makanan mempunyai tugas pokok mengawasi peredaran obat-obatan (termasuk jamu) dan makanan, sehingga kandungannya bisa dipastikan tidak mengganggu kesehatan konsumen. Fungsi penindakan hukumnya sudah barang tentu ada di pihak Kepolisian, karenanya mutlak membutuhkan koordinasi yang baik antar kedua instansi tersebut. Selain fungsi utama pengawasan, Balai Pengawasan Obat dan Makanan juga memiliki fungsi administrasi sebagai bagian integral untuk mendukung efektivitas pelaksanaan fungsi utama. Idealnya, kedua fungsi ini berjalan bersama. Dalam praktiknya, hal ini tidak mudah. Alasanalasan klasik selalu mengemukan, seperti keterbatasan personil, perangkat

25 Nur Rachmat, Penyidikan Dan Pertanggungjawaban Pidana Produsen Terhadap Produk Makanan Mengandung Kimia Berbahaya, Jurnal Ilmu Hukum Legal Opinion, Edisi 4, Volume 2, Tahun 2014. 
laboratorium, anggaran yang minim, dan sebagainya. $^{26}$

Akibatnya, fungsi administrasi yang berimplikasi pada pemberian izin seringkali jauh lebih dikedepankan dibanding fungsi pengawasan. Bukan rahasia lagi, dikalangan pengusaha berlaku anggapan bahwwa izin identik dengan biaya resmi atau tak resmi. Sejumlah pengusaha ada yang berani menempuh berisiko memasarkan suatu produk tanpa izin. Terhadap produk-produk berizin pun, mestinya fungsi pengaasan harus tetap maksimal. Apalagi ada ketentuan secara periodik produsen harus mengirimkan sampel produk ke BPOM untuk diteliti di laboratorium. Bila perlindungan konsumen menjadi concern utama, maka fungsi administrasi (pemberian izin) harus dilaksanakan sebagai bagian integral dari pengawasan. Bukannya terpisah, apalagi kalau pengawasan dinomorduakan dengan alasan sudah terdaftar resmi di Balai Pengawasan Obat dan Makanan. ${ }^{27}$

Ketiga, Faktor Sarana dan Prasarana. Berbicara mengenai fasilitas hukum tidak bisa hanya mengartikannya sebagai infrastruktur semata. Namun, bisa

\footnotetext{
26 I Made Cahyadi, "Pelaksanaan Perlindungan Hukum agi konsumen terhadap peredaran makanan yang telah kadaluarsa di pasar kereneng Denpasar.", Jurnal Ilmu Hukum, Vol. 6, No. 3, Fakultas Hukum, Universitas Udayana, Bali, 2018.

27 Tami Rusli, Tanggung Jawab Produk Dalam Hukum Perlindungan Konsumen, Jurnal Hukum, Vol. 7, No. 2, 2012.
}

juga diartikan sebagai informasi yang cukup dan berguna bagi masyarakat. Mengenai hal tersebut, di Indonesia agaknya hal itu masih kurang memadai. Karena dalam kenyataannya masih banyak konsumen yang menjadi korban atas pelanggaran-pelanggaran yang dilakukan oleh produsen sebagai akibat dari kurangnya informasi mengenai suatu produk yang berbahaya bagi kesehatan. ${ }^{28}$

Keempat, Faktor masyarakat. Kurangnya perhatian konsumen dalam memilih makanan yang aman bagi dirinya sebagai akibat dari keterbatasan pengetahuan, kesadaran dan kemampuan yang bersangkutan serta kurangnya itikad baik dari pihak produsen sehingga terjadi pelanggaran yang pada akhirnya membahayakan kesehatan konsumen, disamping itu konsumen pada umumnya berada pada posisi yang lemah dibanding dengan produsen, baik secara ekonomis, tingkat pendidikan maupun kemampuan atau daya saing dan yang paling mendasar adalah bisnis kalangan usaha kita makin canggih, akibatnya konsumen tidak mampu menyaingi. Kenyataan tersebut merupakan masalah yang timbul dalam bidang

${ }^{28}$ M. Haerandi, Perlindungan Konsumen Terhadap Peredaran Obat Tradisional Ilegal. Allaudin Law Develompent (ALDEV), 2(1), 2020, 6-11. Retrieved from http://journal.unialauddin.ac.id/index.php/aldev/article/download/132 $66 / 8216$. 
pembinaan masyarakat (kesadaran hukum). ${ }^{29}$

Selain hal tersebut, sebagian konsumen enggan mengadukan kerugian yang diderita kepada yang berwajib/penegak hukum dengan alasan yang beragam antara lain: tidak mengetahui kemana harus mengadu; penyelesaian perkara pidana melalui pengadilan memakan waktu yang lama; dan prosedur untuk mengadu ke aparat penegak hukum berbelit-belit.

\section{PENUTUP}

Efektivitas penegakan hukum terhadap produsen makanan berbahaya menuju Indonesia Sehat 2025 tersebut didasarkan apabila pelaku usaha memproduksi dan memperdagangkan produk makanan yang mengandung bahan kimia serta membahayakan kesehatan dan keselamatan konsumen, maka pelaku usaha/produsen melanggar Undang-Undang Nomor 36 Tahun 2009 tentang Kesehatan, Undang-Undang Nomor 18 Tahun 2012 tentang Pangan, Undang-Undang Nomor 8 Tahun 1999 tentang perlindungan Konsumen.

Faktor yang mempengaruhi terhadap efektivitas penegakan hukum terhadap produsen makanan berbahaya

29 Celina Tri Siswi Kristanti, Hukum Perlindungan Konsumen, (Jakarta: Sinar Grafika, 2011), hlm. 169. menuju Indonesia Sehat 2025 ialah faktor hukumnya, yaitu lemahnya sanksi terhadap pelanggarnya, proses penanganan masalah berbelit-belit, kurang profesionalnya para aparatur penegak hukum dan kurangnya koordinasi antar penegak hukum, seperti Balai Pengawasan Obat dan Makanan, Kepolisian, lebih mengutamakan pemberian sanksi perdata dan administrasi Fasilitas Hukum dan pembinaan masyarakat dimana posisi konsumen berada pada posisi yang lemah dibandingkan produsen. Kenyataan tersebut merupakan masalah yang timbul dalam pembinaan masyarakat.

Tanggung jawab pidana produsen terhadap kerugian yang diderita konsumen akibat makanan berbahaya yang diproduksi, dipasarkan, ditawarkan dan diperdagangkannya, secara yuridis, dalam konsepsi Undang-Undang Perlindungan Konsumen dan peraturan perundangundangan terkait lainnya, direalisasikan berdasarkan prinsip tangggung jawab produk (product liability) melalui sistem pembuktian terbalik oleh pelaku usaha/produsen sebagai subjek hukum pidana. Akan tetapi,dilaksanakan dengan tidak menggugurkan kewajiban konsumen untuk membuktikan ada tidaknya unsur melanggar hukum,kerugian dan hubungan kausalitas antara produk yang dikonsumsi dengan kerugian yang dideritanya.

Bagi pihak produsen sebaiknya diberi sosialisasi dan pengarahan lebih 
dalam mengenai pentingnya penegakan hukum terhadap produsen makanan berbahaya menuju indonesia sehat 2025 agar pelaku usaha sadar akan keamanan dan kesehatan, dan tidak merugikan konsumen, karena produsen juga akan mengalami kerugian jika diketahui ada indikasi penggunaan zat berbahaya dalam makanan. Sedangkan bagi Masyarakat, sebagai konsumen harus cerdas dalam mengkonsumsi makanan, selalu perhatikan kemasan apakah terdapat label atau tanda yang memang menyatakan bahwa makanan tersebut aman dikonsumsi.

\section{DAFTAR PUSTAKA}

Achmad Ali. 1998. Menjelajahi Kajian Empiris Terhadap Hukum. Jakarta: Yarsif Watampone.

Celina Tri Siswi Kristanti. 2011. Hukum Perlindungan Konsumen. Jakarta: Sinar Grafika, 2011.

Departemen Kesehatan Republik Indonesis, Rencana Pembangunan Jangka Panjang Bidang Kesehatan, Jakarta, 2009.

Departemen Kesehatan Republik Indonesia, Rencana Pembangunan Jangka Panjang Bidang Kesehatan, Jakarta, 2009.

Departemen Pendidikan Nasional, 1990. Kamus Besar Bahasa Indonesia, Jakarta Balai Pustaka.

H.E Saefullah. 1991. Hukum Perlindungan Konsumen Di Indonesia. Bandung: Citra Aditya Bakti.

Hartarto Winoto. 2000. Perlindungan Hukum Konsumen. Jakarta: Salemba Empat.

I Made Cahyadi, "Pelaksanaan Perlindungan Hukum agi konsumen terhadap peredaran makanan yang telah kadaluarsa di pasar kereneng Denpasar.”, Jurnal Ilmu Hukum, Vol. 06, no. 03, Fakultas Hukum, Universitas Udayana, Bali.2018.

Ditjen PPM \& PL., Prinsip Hygiene dan

Sanitasi Makanan, Jakarta, 2001.

Liss Dyah Dewi Arini, Faktor-Faktor Penyebab Dan Karakteristik Makanan Kadaluarsa Yang Berdampak Buruk Pada Kesehatan Masyarakat, Jurnal APIKES, Surakarta, Citra Medik, 2017.

M. Haerandi, Perlindungan Konsumen Terhadap Peredaran Obat Tradisional Ilegal. Allaudin Law Develompent (ALDEV), 2(1), 2020, 6-11. Retrieved from http://journal.unialauddin.ac.id/index.php/aldev/arti cle/download/13266/8216.

Muhammad Rusydi Ridha, Efektivitas Penegakan Hukum Pidana Kesehatan Dalam Bidang Obat Dan Makanan Di Indonesia, Tesis, Program Masgister Ilmu Hukum Program Pascasarjana Fakultas Hukum Universitas Islam Indonesia, 2017, hlm. 6.

Nita Dkk, Penegakan Hukum Pidana Terhadap Produsen Pangan Yang Mengandung Zat Berbahaya, Journal Fakultas Hukum, 2017, hlm. 3.

Nur Rachmat, Penyidikan Dan Pertanggungjawaban Pidana Produsen Terhadap Produk Makanan Mengandung Kimia Berbahaya, Jurnal Ilmu Hukum Legal Opinion, Edisi 4, Volume 2, Tahun 2014, hlm. 40.

Nur Rachmat, Penyidikan Dan Pertanggungjawaban Pidana Produsen Terhadap Produk Makanan Mengandung Kimia Berbahaya. Jurnal Ilmu Hukum Legal Opinion, Edisi 4, Volume 2, Tahun 2014.

Roy A Sparringa, Laporan Tahunan Badan Pengawas Obat dan Makanan 
Republik Indonesia tahun 2014, Badan POM RI, Februari 2015.

Satjipto Rahardjo. 2012. Ilmu Hukum. Bandung: Citra Aditya Bakti.

Soerjono Soekanto. 1988. Efektivitas Hukum dan Penerapan Sanksi. Bandung: Ramadja Karya.
Tami Rusli, Tanggung Jawab Produk Dalam Hukum Perlindungan Konsumen, Jurnal Hukum.Vol. 7, No. 2, 2012.

Yusuf Shofie. 2008. Kapita Selekta Hukum Perlindungan Konsumen Di Indonesia, Bandung: Citra Aditya Bakti. 